\title{
Birçok Sistemik Hastalığı Olan Bir Hastada Retina Sinir Lifi Tabakasında İncelme
}

\section{Decreased Retinal Nerve Fiber Layer Thickness in a Patient with Multiple Systemic Diseases}

Zeynep Dadacı ${ }^{1}$,

Cengiz Kadıyoran²,

Hilal Akay Çizmecioğlu ${ }^{3}$

${ }^{1}$ Medova Hastanesi, Göz Hastalıları Kliniği, Konya

${ }^{2}$ Necmettin Erbakan Üniversitesi Meram Tıp

Fakültesi Radyoloji Anabilim Dalı, Konya

${ }^{3}$ Akademi Hastanesi, İ̧ Hastalıkları Kliniği

Konya

Geliş Tarihi/Received: 17 Şubat 2018

Kabul Tarihi/Accepted: 03 Nisan 2018

\begin{abstract}
Öz
Retina sinir lifi tabakasındaki incelme başta glokom olmak üzere, çeşitli nörolojik hastalıklar, optik sinirin glokom dışı bozuklukları, retina hastalıkları, toksik, nutrisyonel veya şok optik nöropatisi gibi vasküler nedenlere bağlı gelişebilir. Dünyadaki en sık körlük nedenlerinden biri olan glokom, retina ganglion hücre ölümüne bağlı olarak retina sinir lifi tabakasında incelme, optik sinir başında çukurlaşma ve görme alanı kaybı ile karakterize ilerleyici bir optik nöropatidir. Glokomla ilişkisi en iyi bilinen risk faktörü yüksek göz içi basıncı olmasına rağmen glokom risk faktörleri arasında yer alan sistemik vasküler bozuklukların özellikle göz içi basıncın düşük seyrettiği normotansif glokomun patogenezinde rol oynadığı düşünülmektedir. Çalışmamızda birçok sistemik hastalıkla beraber retina sinir lifi tabakasında incelme olan ve en olası tan olarak normotansif glokom düşündüğümüz bir olguyu tarif ettik.
\end{abstract}

Anahtar Kelimeler: Retina sinir lifi tabakası, normotansif glokom, sistemik hastalık

\begin{abstract}
A decrease in retinal nerve fiber layer thickness can be secondary to glaucoma, several neurologic diseases, optic nerve diseases other than glaucoma, retinal diseases, toxic, nutritional or vascula causes such as shock optic neuropathy. Glaucoma, which is among the commonest causes of blindness worldwide, is a progressive optic neuropathy characterized by a decrease in retinal nerve fiber layer thickness secondary to retinal ganglion cell death, cupping of optic nerve head and visual field loss Although the best known risk factor associated with glaucoma is high intraocular pressure, it is thought that systemic vascular disorders, which are among the risk factors of glaucoma, play role especially in the pathogenesis of normotensive glaucoma where intraocular pressure is low. In our study, we described a patient with decreased retinal nerve fiber layer thickness and thought normotensive glaucoma as the most probable diagnosis, who also had multiple systemic diseases.
\end{abstract}

Key words: Retinal nerve fiber layer, normotensive glaucoma, systemic disease

\section{GiRiş}

Retina sinir lifi tabakasındaki incelme başta glokom olmak üzere, çeşitli nörolojik hastalıklar, optik sinirin glokom dışı bozuklukları, retina hastalıkları, toksik, nutrisyonel veya şok optik nöropatisi gibi vasküler nedenlere bağlı gelişebilir. Retina sinir lifi tabakasında incelme ve optik sinir başında çukurlaşmaya yol açan ve ilerleyici bir optik nöropati olan glokom dünyadaki körlük nedenleri arasında ilk sıralarda yer almaktadır. Çeşitli çalışmalarda glokomun 40 yaş üzeri popülasyonda görülme sıklığı \%2 olarak bildirilmiştir (1). Glokomla ilişkili risk faktörleri ailede glokom öyküsü, ileri yaş, diyabet, hipertansiyon/hipotansiyon gibi sistemik hastalıklar ile yüksek göz içi basıncı gibi göz ait nedenlerdir (1).

Tüm glokomların büyük kısmını oluşturan primer açık açılı glokom ön kamara açısının açık olması, ilerleyici görme alanı kaybı ve göz içi basıncının (GIB) yüksek olmasıyla karakterizedir (2). Daha nadir

Yazıșma Adresi: Zeynep Dadacı, Medova Hastanesi, Göz Hastalıkları Kliniği, Konya e-posta: zdadaci@hotmail.com

Atıf yapmak için:Dadacı Z, Kadıyoran C, Çizmecioğlu HA. Birçok Sistemik Vasküler Hastalığı Olan Bir Hastada Retina Sinir Lifi Tabakasında İncelme. Selcuk Med J 2018;34(4): 183-185 görülen normotansif glokomda (NTG) ise GỉB'nın normal sınırlarda izlenmesinin dışındaki diğer belirti ve bulgular primer açık açılı glokomla aynıdır (3).

Glokomun etiyolojisi kesin olarak bilinmemekle beraber hastalıkla ilişkili olarak birçok risk faktörü tanımlanmıştır. Bu risk faktörleri arasında en iyi bilineni yükselmiş GiB olsa da vasküler faktörlerin de glokom patogenezinde önemli rolü olduğu görüşü giderek artan oranda kabul görmektedir. Özellikle NTG'da vasküler faktörlerin rolünün ön planda olduğu düşünülmektedir $(4,5)$.

Çalışmamızda birçok sistemik hastalıkla beraber retina sinir lifi tabakasında belirgin incelme olan ve en olası tanı olarak NTG düşündüğümüz bir olguyu tarif ettik.

\section{OLGU SUNUMU}

78 yaşında erkek hasta bulanık görme şikayeti ile polikliniğimize başvurdu. Oftalmolojik muayenesinde 


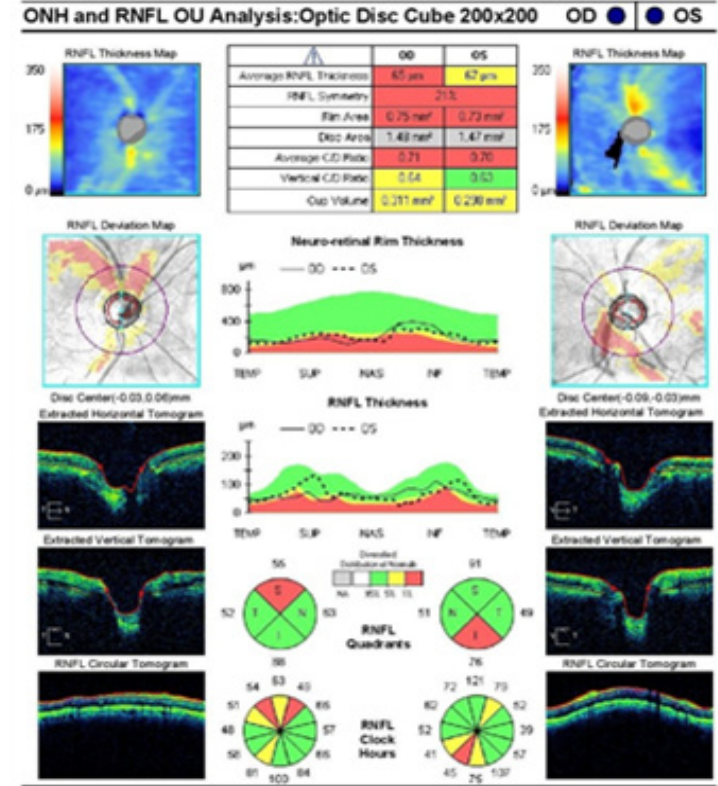

Şekil 1. Optik kohorens görüntülemede özellikle üst ve alt kadranlarda belirgin hasar izleniyor.

düzeltilmiş en iyi uzak görme keskinliği sağ gözde 20/25, sol gözde 20/32 (Snellen Eşeli) idi. Biyomikroskopik incelemesinde bilateral nükleer kataraktı tesbit edilen hastanın dilatasyonlu göz dibi muayenesinde diyabetik retinopati gözlenmedi. Renkli görme her iki gözde normal izlendi ve rölatif aferent pupil defekti yoktu. Gonyoskopik incelemede ön kamara açısı açık izlendi. Ayrıca her iki gözde optik sinir başında çukurlaşma oranları 0,7 düzeyinde ve peripapiller atrofi alanı mevcut idi. Diurnal olarak aplanasyon tonometrisi ile ölçülen göz içi basınçlarının ortalaması sağ gözde 12, sol gözde $14 \mathrm{mmHg}$ idi. Santral kornea kalınlıkları sağ gözde 536, sol gözde 553 mikron olarak ölçüldü. Hastanın sistemik hastalık sorgulamasında, 7 yıldır Tip 2 diyabeti olduğu, kronik iskemik kalp hastalığı nedeniyle 6 yıl önce koroner stent uygulandığı, 4 yıl önce serebrovasküler olay geçirdiği ve periferik arter hastalığı olduğu öğrenildi. Kraniyal manyetik rezonans (MR) görüntülemede kafa içi veya orbital kitle izlenmedi. Hastanın çekilen optik kohorens tomografisinde özellikle üst ve alt kadranlarda sinir lifi tabakasında incelme izlendi (Şekil 1). Ortalama retina sinir lifi kalınlığı sağ gözde 65 ve sol gözde 67 mikrondu. Koopere olmadığından hastaya görme alanı çekilemedi.

\section{TARTIŞMA}

Glokom için risk faktörleri; yüksek göz içi basıncı gibi göze ait faktörler, ailede glokom öyküsü, ileri yaş ile diyabet, hipertansiyon/hipotansiyon, vazospazm ve migren gibi vasküler faktörlerdir (1). Bizim olgumuzda da göz içi basınç ölçümleri normal olmasına rağmen ilerlemiş retina sinir lifi tabakası hasarı tespit ettik. Sinir lifi tabakasındaki hasarın bilateral olması, retina muayenesinin normal olması, optik sinirde belirgin glokomatöz çukurlaşma ve peripapiller atrofi alanının varlığı nedeniyle hastada en olası tanının NTG olduğunu düşündük. Glokom tanısının desteklenmesinde ve nörolojik nedenler başta olmak üzere diğer hastalıklardan ayırıcı tanının yapılmasında önemli yeri olan görme alanı testini hastamızda uygulayamadığımız için hastaya önerdiğimiz kraniyal MR görüntülemede herhangi bir kompresif patoloji tespit etmedik. Belirgin çukurlaşma dışında optik sinirde genel solukluk, konjenital disk hastalığı, drusen gibi patalojilerin olmaması ve hastanın renk görmesinin normal ve rölatif aferent pupil defektinin olmaması da bizi ayırıcı tanıda NTG ile karışabilecek iskemik optik nöropati ve diğer nedenlerden uzaklaştırdı. Yine de eski steroid kullanımı, geçmiş pigmenter glokomun inaktif hale gelmesi gibi nedenlerle geçmişteki yüksek göz içi basıncına bağlı oluşmuş optik sinir hasarı da dışlanması kolay olmayan ve ayırıcı tanıda düşünülmesi gereken diğer hususlardır. Hastamızda NTG ile ilişkili olabileceği bildirilen diyabet, kronik iskemik kalp hastalığı, serebro vasküler olay ve periferik vasküler hastalık birlikte bulunmaktaydı. Birçok sistemik hastalığın bir arada bulunması yaygın vasküler endotel hasarı, oksidatif stress ve lokal oküler perfüzyon dinamiklerinin bozulması gibi mekanizmalar yoluyla görme sinirinin progresif iskemik hasarına ve sonuç olarak NTG gelişimine neden olabilir.

Normotansif glokomun kesin patogenezi bilinmemekle beraber, optik sinir başının hipoperfüzyonuna bağlı gelişen kronik progresif iskemik bir bozukluk olduğuna işaret eden birçok çalışma bulunmaktadır (5,6). 2012 yılında yayınlanan bir çalışmada yanıp sönen ışığa karşı gelişen retinal vasküler reaktivite, karotis intima-media kalınlığı ve nabız dalga analizi yöntemiyle gösterilen mikro- ve makrovasküler bozuklukların NTG'lu olgularda kontrol grubuna kıyasla daha fazla bulunduğu bildirilmiştir. Yazarlar çalışmalarının sonucunda NTG'un oluşum ve ilerlemesinde vasküler patolojilerin birçok seviyede değerlendirilmesi gerekliliğini vurgulamıştır(5). Hayreh ve ark. anterior iskemik optik nöropati, NTG, primer açık açılı glokom ve diğer optik sinir başı bozuklukları olan hastalarda yaptıkları çalışmada nokturnal hipotansiyonun NTG'lu hastalarda istatistiksel olarak 
anlamlı oranda daha fazla görüldüğünü bildirmişlerdir. Yazarlar nokturnal hipotansiyonun optik sinir başı kan akımını kritik seviyenin altına düşürerek glokomatöz optik nöropatinin patogenezinde rol oynayabileceğini belirtmişlerdir (6).

Literatürde, oküler vasküler faktörlerin yanı sıra sistemik bazı hastalıkların da NTG'la ilişkisi bildirilmiştir (7). Primer açık açılı glokom, NTG ve oküler hipertansiyonu olan 4920 hasta üzerine yapılan bir araştırmada oküler hipertansiyonlu grupta hiç vasküler risk faktörü olmayan olguların oranı diğer gruplardan daha fazla bulunmuştur. Primer açık açılı glokomu olan grupta 3 yıldan fazla süre takip sonrasında en az iki vasküler risk faktörü olan olgularda görme alanında bozulma \%16 oranındayken, en az üç vasküler risk faktörü olanlarda görme alanında bozulma oranının \%42 olduğu gösterilmiştir (7). Yine birçok geniş ölçekli çalışmada diyabet, hipertansiyon, hipotansiyon ve ateroskleroz gibi sistemik hastalıklarda glokom riskinin arttığı bildirilmiştir (8-11). Fakat diğer taraftan böyle bir ilişkinin tespit edilmediği araştırmalar da mevcuttur $(12,13)$. Bu çelişkinin nedeni optik sinir kan akımının otoregülasyon mekanizmasıyla birçok kişide normal sınırlarda tutulabiliyor olması olabilir.

Göz içi basıncının normal sınırlarda ölçülmesi ve çoğu zaman hastaların görme alanı kaybı iyice ilerleyene kadar herhangi bir şikayetlerinin olmaması nedeniyle NTG tanısının konulması güç olabilir. Glokomun ilerlemesiyle oluşan optik sinir hasarı ve görme kaybı geri dönüşümsüzdür. Fakat uygun tedavi ile hastalığın ilerlemesi önlenebilir $(2,3)$. Glokom tanısının atlanmaması, erken tanı ve tedavinin yapılabilmesi için özellikle optik disk muayenesinin iyi yapılması ve glokom için risk faktörü olabilecek bazı sistemik hastalıkları olan olguların bu açıdan değerlendirilmesi gerekmektedir. Vasküler risk faktörleri bulunan bireylerde, özellikle optik sinir başında çukurlaşma ve peripapiller atrofi gözlenmesi durumunda glokomdan şüphelenilmelidir.

Çıkar Çatışması: Çalışmada herhangi bir çıkar çatışması yoktur.

Finansal Çıkar Çatışması: Çalışmada herhangi bir finansal çıkar çatışması yoktur.

Yazışma Adresi: Zeynep Dadacı, Havzan Mah. Yeni Elektrik Santral Cad. Altınbaşak Konakları 4C/4 Konya

Tel: +905337269070 e-mail: zdadaci@hotmail.com

\section{KAYNAKLAR}

1. Yanoff M, Duker JS. Ophthalmology. Second edition. St. Louis: Mosby 2004:1413-7.

2. Weinreb RN, Khaw PT. Primary open-angle glaucoma.
Lancet 2004;363(9422):1711-20.

3. Anderson DR. Normal-tension glaucoma (Low-tension glaucoma). Indian J Ophthalmol. 2011;59 Suppl:S97-101.

4. Doyle A, Bensaid A, Lachkar Y. Central corneal thickness and vascular risk factors in normal tension glaucoma. Acta Ophthalmol Scand 2005;83(2):191-5.

5. Mroczkowska S, Ekart A, Sung V, et al. Coexistence of macroand micro-vascular abnormalities in newly diagnosed normal tension glaucoma patients. Acta Ophthalmol (Copenh). 2012;90(7):e553-9.

6. Hayreh SS, Zimmerman MB, Podhajsky P, et al. Nocturnal arterial hypotension and its role in optic nerve head and ocular ischemic disorders. Am J Ophthalmol 1994;117(5):603-24.

7. Zeyen T, Belgian Glaucoma Society. Screening for vascular risk factors in glaucoma: The GVRF study. Bull Société Belge Ophtalmol 2005;(298):53-60.

8. Mitchell P, Smith W, Chey $\mathrm{T}$, et al. Open-angle glaucoma and diabetes: The Blue Mountains eye study, Australia. Ophthalmology 1997;104(4):712-8.

9. Mitchell P, Lee AJ, Rochtchina E, et al. Open-angle glaucoma and systemic hypertension: The blue mountains eye study. J Glaucoma 2004;13(4):319-26.

10. Kaiser HJ, Flammer J, Graf T, et al. Systemic blood pressure in glaucoma patients. Graefes Arch Clin Exp Ophthalmol Albrecht Von Graefes Arch Für Klin Exp Ophthalmol 1993;231(12):677-80.

11. Güngör IU, Güngör L, Ozarslan $Y$, et al. Is symptomatic atherosclerotic cerebrovascular disease a risk factor for normal-tension glaucoma? Med Princ Pract Int J Kuwait Univ Health Sci Cent 2011;20(3):220-4.

12. Ellis JD, Evans JM, Ruta DA, et al. Glaucoma incidence in an unselected cohort of diabetic patients: Is diabetes mellitus a risk factor for glaucoma? DARTS/MEMO collaboration. Diabetes Audit and Research in Tayside Study. Medicines Monitoring Unit. Br J Ophthalmol 2000;84(11):1218-24.

13. De Voogd S, Wolfs RCW, Jansonius NM, et al. Atherosclerosis, C-reactive protein, and risk for open-angle glaucoma: The Rotterdam study. Invest Ophthalmol Vis Sci 2006;47(9):3772-6. 